\title{
Mutagenic Effectivity of Cadmium Sulphide and Copper Oxide Nanoparticles on Some Physiological and Cytological Attributes of Lathyrus sativus L.
}

\author{
Bapi Ghosh ${ }^{1}$, Animesh Kumar Datta ${ }^{1 *}$, Ankita Pramanik ${ }^{1}$, \\ Divya Vishambhar Kumbhakar ${ }^{1}$, Debadrito Das ${ }^{1}$, Rita Paul ${ }^{2}$ and Jayita Biswas ${ }^{3}$ \\ ${ }^{1}$ Department of Botany, Cytogenetics, Genetics and Plant Breeding Section, University of Kalyani, \\ Kalyani 741235, West Bengal, India \\ ${ }^{2}$ Department of Botany, Charuchandra College, Kolkata 700029, West Bengal, India \\ ${ }^{3}$ Department of Botany, Pteridology and Palaeobotany Section, University of Kalyani, \\ Kalyani 741235, West Bengal, India
}

Received July 5, 2016; accepted March 5, 2017

\begin{abstract}
Summary Dry seeds (moisture content: $17.50 \%$ ) of Lathyrus sativus L. (Family: Fabaceae, common namegrass pea) are exposed (doses: $0.25,0.50$ and $1.00 \mu \mathrm{g} \mathrm{mL}^{-1}$, duration: 3 and $6 \mathrm{~h}$ ) to chemically synthesized cadmium sulphide and copper oxide nanoparticle (NP) treatments for assessment of genotoxic potentiality. The objective of the work is to foresee whether the NPs possess effective mutagenic potentiality. Result is significant in the direction of underlined objective.
\end{abstract}

Key words Lathyrus sativus, CdS-NP, CuO-NP, Physiological and cytological attributes, Mutagenic potentiality.

Nanoparticles (NPs; size $<100 \mathrm{~nm}$ ) possess significant uses in industry, biomedical sciences and electronic devices (Manickathai et al. 2008, Masarovičová and Králová 2013), plant biotechnology and agriculture (Scrinis and Lyons 2007) including crop protection (Nair et al. 2010). NP-mediated plant interaction is opening a new dimension of research on induced mutagenesis (Halder et al. 2015a, 2015b, Kumbhakar et al. 2016). Doses of NPs administered and species level sensitivity are significant pre-requisites for designing experiments on mutation breeding. With the view to it, the present investigation describes the effective potentiality of chemically synthesized $\mathrm{CdS}$ and $\mathrm{CuO}-\mathrm{NPs}$ (semiconductor NPs; band gap-CdS: $2.45 \mathrm{eV}, \mathrm{CuO}: 3.149 \mathrm{eV}$ ) on some physiological (Petri plate seed germination and seedling length-for the assessment of phytotoxicity) and cytological (mitotic aberrations-for determination of genotoxicity) attributes of Lathyrus sativus L. (Family: Fabaceae; common name-grass pea, a legume of commercial importance).

Materials and methods

\section{Germplasm}

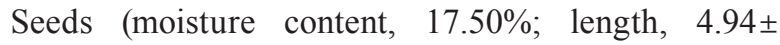
$0.09 \mathrm{~mm}$; breadth, $4.40 \pm 0.13 \mathrm{~mm}$ ) of L. sativus were obtained from Horticultural Research Station, Director-

\footnotetext{
*Corresponding author, e-mail: dattaanimesh@gmail.com DOI: $10.1508 /$ cytologia. 82.267
}

ate of Principle Agriculture Officer, Nadia, Govt. of West Bengal, India.

\section{Preparation of NPS}

CdS-NPs were prepared following wet chemical co-precipitation techniques adopted by Halder et al. (2015a). CuO-NPs were chemically synthesized according to Topnani et al. (2010). Bulk compounds were prepared without the application of capping agents.

Both the NPs were characterized based on different opto-physical parameters (data unpublished). Instrumentation techniques revealed corroborating result of the size and shape for both the nano-crystals and they were with conformation of the nano-standard quality.

\section{Treatments}

Dry seeds of L. sativus were treated with $\mathrm{CdS}$ and CuO-NPs (doses: 0.25, 0.50 and $1.00 \mu \mathrm{g} \mathrm{mL}^{-1}$; duration: 3 and $6 \mathrm{~h}$ ). Controls (dry: bulk $\mathrm{CdS}-0.25 \mu \mathrm{g} \mathrm{mL}^{-1}, 3 \mathrm{~h}$ and bulk $\mathrm{CuO}-0.25 \mu \mathrm{g} \mathrm{mL}^{-1}, 3 \mathrm{~h}$ ) were also kept for assessment. A hundred seeds were exposed in each lot of treatments.

\section{Seed germination and seedling growth}

Treated and control seeds (100 in each case) were given in Petri plates lined with moist filter paper $\left(28 \pm 1^{\circ} \mathrm{C}\right)$. Emergence of radicle was considered as index of germination. Twenty randomly selected seedlings from each set were measured on the seventh day from treatments in a millimeter graph paper. Lethality and injury were 
calculated from germination frequency and seedling length, respectively (Konzak et al. 1965), and represented as percent of controls (bulk $\mathrm{CdS}$ and $\mathrm{CuO}$ ).

\section{Mitotic study}

Germinating roots of about $2 \mathrm{~mm}$ in length from each set (three to four) were cut at uniform duration (12 noon to $12: 30$ p.m.), fixed in $1: 3(\mathrm{v} / \mathrm{v})$ acetic alcohol overnight and stored in $70 \%$ alcohol in a refrigerator $\left(16 \pm 1^{\circ} \mathrm{C}\right)$. Roots were stained in orcein- $\mathrm{HCl}(9: 1)$ mixture for 3 to $4 \mathrm{~h}$ following standard hydrolysis procedure. Root tips were squashed in $45 \%$ acetic acid and observed under an Olympus trinocular light microscope (Magnüs MLXDX).

Mitotic index [(total number of dividing cells/total cells scored) $\times 100$ ], types of aberration (both in dividing and resting cells) and total abnormality percentage in dividing cell were assessed. Photomicrographs were taken from suitable squash preparations.

\section{Results and discussion}

\section{Germination frequency and seedling growth}

Results of seed germination frequency and seedling length are presented in Table 1. Inhibition in seed germination frequency is recorded in treatments (CdS-NPs: 92.0-76.0\%; CuO-NPs: 90.0-72.0\%) than controls (dry: 96.0\%, bulk CdS: $94.0 \%$ and bulk $\mathrm{CuO}: 93.0 \%$ ) and is marked in higher doses $\left(1.00 \mu \mathrm{g} \mathrm{mL}^{-1}, 6 \mathrm{~h}\right)$. Seedling length also reduces significantly $(p<0.05)$ in treatments (CdS-NPs: $24.82 \pm 1.19$ to $11.33 \pm 0.61 \mathrm{~mm}$; CuO-NPs: $17.28 \pm 0.62$ to $9.44 \pm 0.46 \mathrm{~mm}$ ) than controls. Maximum reduction is observed in $0.25 \mu \mathrm{g} \mathrm{mL}^{-1}, 3 \mathrm{~h}$ for CdS-NPs and $1.00 \mu \mathrm{g} \mathrm{mL}^{-1}, 3 \mathrm{~h}$ for CuO-NPs. On comparative basis of unit doses of NPs, it seems that germination frequency is relatively more affected in $\mathrm{CuO}-\mathrm{NPs}$ treatment, while seedling growth did not manifest any clear response.

Assessment of lethality indicates that none of the employed doses has shown $50.0 \%$ reduction in germination. It suggests that the doses of NPs administered are tolerant to the genotype. Injury ranges from 8.62 to $58.28 \%$ in CdS-NPs and 13.08 to $52.52 \%$ in CuO-NPs. The inhibitory action of NPs on the studied physiological attributes accentuates induction of phytotoxicity. NPs are reported to inhibit seed germination, seedling growth, and root elongation among others in different plant species (Lee et al. 2010, Ma et al. 2010, Atha et al. 2012, Shaymurat et al. 2012, Kumbhakar et al. 2016), thereby conferring phytotoxicity. However, enhancement in different physiological attributes has also been studied (Lu et al. 2002, Lin et al. 2004, Masarovičová and Král'ová 2013).

Reduction in germination frequency and seedling growth as the consequence of mutagen treatments have been attributed to the nature and the extent of chromosomal aberration occurring in the cells (Sax 1942, Lea 1946, Read 1959, Evans and Sparrow 1961, Datta and Biswas 1983) and also to structural changes (Gray and Read 1950).

\section{Mitotic study}

Compared to controls, mitotic index reduces significantly $(p<0.05)$ in treatments; while types and total aberration frequency estimated from dividing cells (show dose dependent relationship) enhances (Table 2) significantly $(p<0.05)$. NPs are therefore producing mitodepressive and genotoxic effects. Evans (1965) consid-

Table 1. Germination frequency and seedling length in controls and NP treatments.

\begin{tabular}{|c|c|c|c|c|c|c|c|}
\hline \multirow{2}{*}{ Doses $\left(\%, \mu \mathrm{g} \mathrm{mL}^{-1}\right)$} & \multirow{2}{*}{ Duration (h) } & \multirow{2}{*}{$\begin{array}{l}\text { Total no. of seeds } \\
\text { given in Petri plate }\end{array}$} & \multirow{2}{*}{$\begin{array}{l}\text { Germination } \\
\text { frequency (\%) }\end{array}$} & \multicolumn{2}{|c|}{ Seedling length (mm) } & \multirow{2}{*}{ Lethality* } & \multirow{2}{*}{ Injury* } \\
\hline & & & & Mean & SE & & \\
\hline Dry control & & 100 & 96.0 & 29.01 & 1.11 & - & - \\
\hline Bulk CdS control & 3 & 100 & 94.0 & 27.16 & 0.92 & - & - \\
\hline \multicolumn{8}{|l|}{ CdS-NPs } \\
\hline 0.25 & 3 & 100 & 92.0 & 11.33 & 0.61 & 2.13 & 58.28 \\
\hline 0.50 & 3 & 100 & 87.0 & 13.82 & 0.73 & 7.45 & 49.12 \\
\hline 1.00 & 3 & 100 & 86.0 & 24.82 & 1.19 & 8.51 & 8.62 \\
\hline 0.25 & 6 & 100 & 90.0 & 14.43 & 0.61 & 4.26 & 46.87 \\
\hline 0.50 & 6 & 100 & 82.0 & 19.76 & 0.84 & 12.77 & 27.25 \\
\hline 1.00 & 6 & 100 & 76.0 & 16.34 & 0.89 & 19.15 & 39.84 \\
\hline Bulk $\mathrm{CuO}$ control & 3 & 100 & 93.0 & 19.88 & 0.70 & - & - \\
\hline \multicolumn{8}{|l|}{$\mathrm{CuO}-\mathrm{NPs}$} \\
\hline 0.25 & 3 & 100 & 90.0 & 17.28 & 0.62 & 3.23 & 13.08 \\
\hline 0.50 & 3 & 100 & 83.0 & 11.25 & 0.55 & 10.75 & 43.41 \\
\hline 1.00 & 3 & 100 & 78.0 & 9.44 & 0.46 & 16.13 & 52.52 \\
\hline 0.25 & 6 & 100 & 88.0 & 16.12 & 0.51 & 5.38 & 18.91 \\
\hline 0.50 & 6 & 100 & 82.0 & 14.21 & 0.66 & 11.83 & 28.52 \\
\hline 1.00 & 6 & 100 & 72.0 & 12.67 & 0.64 & 22.58 & 36.27 \\
\hline $\mathrm{CD}$ at $5 \%$ level & & & & 0.95 & & & \\
\hline
\end{tabular}

\footnotetext{
* Percent of control.
} 
Table 2. Mitotic index and frequency of aberration types in controls and NP treatments.

\begin{tabular}{|c|c|c|c|c|c|c|c|c|c|c|c|c|c|c|c|c|}
\hline \multirow{3}{*}{$\begin{array}{l}\text { Mitotic index }(\%) \text { and } \\
\text { categorization of } \\
\text { aberration types }\end{array}$} & \multirow{3}{*}{$\begin{array}{c}\text { Dry } \\
\text { control }\end{array}$} & \multirow{3}{*}{$\begin{array}{c}\text { Bulk CdS } \\
\text { control }\end{array}$} & \multicolumn{6}{|c|}{ CdS-NPs $(\mu \mathrm{gmL}-1)$} & \multirow{3}{*}{$\begin{array}{l}\text { Bulk } \\
\text { CuO } \\
\text { control }\end{array}$} & \multicolumn{6}{|c|}{ CuO-NPs $(\mu \mathrm{g} m L-1)$} & \multirow{3}{*}{$\begin{array}{l}\text { CD } \\
\text { at } 5 \% \\
\text { level }\end{array}$} \\
\hline & & & \multicolumn{3}{|c|}{$3 \mathrm{~h}$} & \multicolumn{3}{|c|}{$6 \mathrm{~h}$} & & \multicolumn{3}{|c|}{$3 \mathrm{~h}$} & \multicolumn{3}{|c|}{$6 \mathrm{~h}$} & \\
\hline & & & 0.25 & 0.50 & 1.00 & 0.25 & 0.50 & 1.00 & & 0.25 & 0.50 & 1.00 & 0.25 & 0.50 & 1.00 & \\
\hline $\begin{array}{l}\text { Mitotic index (\%) } \\
\text { Physiological }\end{array}$ & 19.43 & 17.01 & 10.72 & 8.16 & 14.34 & 9.60 & 7.08 & 11.84 & 15.95 & 10.06 & 12.11 & 13.65 & 11.12 & 13.22 & 14.75 & 0.85 \\
\hline $\begin{array}{l}\text { 1. Stickiness } \\
\text { 2. Fragmentation }\end{array}$ & 0.42 & 2.04 & 3.29 & 3.45 & 2.95 & 5.29 & 5.52 & 4.77 & 2.50 & 2.35 & 3.06 & 4.17 & 2.47 & 3.34 & 5.00 & \\
\hline a. Metaphase & & & & & & & & & & & & & & & & \\
\hline i. Gap & 0.00 & 0.00 & 0.62 & 0.73 & 0.70 & 1.18 & 0.69 & 1.32 & 0.00 & 0.84 & 0.87 & 0.91 & 0.93 & 0.56 & 0.78 & \\
\hline $\begin{array}{l}\text { ii. Fragments including paired fragments } \\
\text { b. Anaphase }\end{array}$ & 0.00 & 0.00 & 1.03 & 0.73 & 0.98 & 0.88 & 0.92 & 1.15 & 0.00 & 0.67 & 0.73 & 1.09 & 0.62 & 0.84 & 1.25 & \\
\hline $\begin{array}{l}\text { i. Paired fragments } \\
\text { c. Resting cells }\end{array}$ & 0.00 & 0.00 & 0.82 & 0.91 & 0.84 & 1.18 & 1.15 & 1.48 & 0.00 & 0.50 & 1.16 & 0.73 & 0.62 & 0.56 & 0.94 & \\
\hline i. Micronuclei & 0.00 & 0.00 & 0.00 & 0.13 & 0.21 & 0.00 & 0.18 & 0.27 & 0.00 & 0.00 & 0.24 & 0.49 & 0.17 & 0.32 & 0.51 & \\
\hline $\begin{array}{l}\text { 3. Inter-and intra-chromosomal rearrangeme } \\
\text { a. Metaphase }\end{array}$ & ents & & & & & & & & & & & & & & & \\
\hline $\begin{array}{l}\text { i. Ring } \\
\text { b. Anaphase }\end{array}$ & 0.00 & 0.00 & 0.00 & 0.00 & 0.28 & 0.00 & 0.23 & 0.82 & 0.00 & 0.00 & 0.29 & 0.73 & 0.00 & 0.97 & 1.25 & \\
\hline i. Bridges & 0.00 & 0.00 & 1.23 & 1.09 & 2.24 & 2.35 & 2.07 & 2.80 & 0.00 & 1.01 & 1.31 & 1.20 & 1.85 & 1.95 & 2.50 & \\
\hline 4. Pseudochiasma & 0.00 & 0.00 & 2.26 & 2.36 & 1.68 & 2.35 & 2.53 & 2.14 & 0.00 & 1.68 & 1.46 & 2.54 & 1.55 & 1.25 & 2.34 & \\
\hline $\begin{array}{l}\text { 5. Spindle aberration } \\
\text { a. Metaphase }\end{array}$ & & & & & & & & & & & & & & & & \\
\hline $\begin{array}{l}\text { i. Polyploid } \\
\text { b. Anaphase }\end{array}$ & 0.00 & 0.00 & 0.41 & 1.27 & 1.40 & 0.88 & 1.38 & 1.64 & 0.00 & 0.84 & 1.16 & 1.81 & 0.77 & 1.53 & 1.86 & \\
\hline i. Laggards & 0.00 & 0.00 & 1.03 & 1.27 & 1.82 & 2.06 & 2.07 & 1.97 & 0.19 & 0.67 & 1.60 & 2.18 & 1.39 & 1.67 & 2.19 & \\
\hline ii. Tripolarity & 0.00 & 0.00 & 0.62 & 0.73 & 0.70 & 1.47 & 1.38 & 2.30 & 0.00 & 1.51 & 1.46 & 2.36 & 1.55 & 2.09 & & \\
\hline 6. Metabolic defects & & & & & & & & & & & & & & & & \\
\hline a. Giant cells & 0.00 & 0.00 & 0.00 & 0.15 & 0.26 & 0.00 & 0.19 & 0.29 & 0.00 & 0.17 & 0.28 & 0.37 & 0.23 & 0.34 & 0.41 & \\
\hline b. Giant cell with vacuoles & 0.00 & 0.00 & 0.00 & 0.00 & 0.05 & 0.00 & 0.00 & 0.07 & 0.00 & 0.00 & 0.00 & 0.06 & 0.00 & 0.04 & 0.16 & \\
\hline Total abnormality (\%) in dividing cells & 0.42 & 2.04 & 11.32 & 12.52 & 13.60 & 17.65 & 18.85 & 20.39 & 2.70 & 10.08 & 13.10 & 18.51 & 11.75 & 14.76 & 20.78 & 0.84 \\
\hline
\end{tabular}
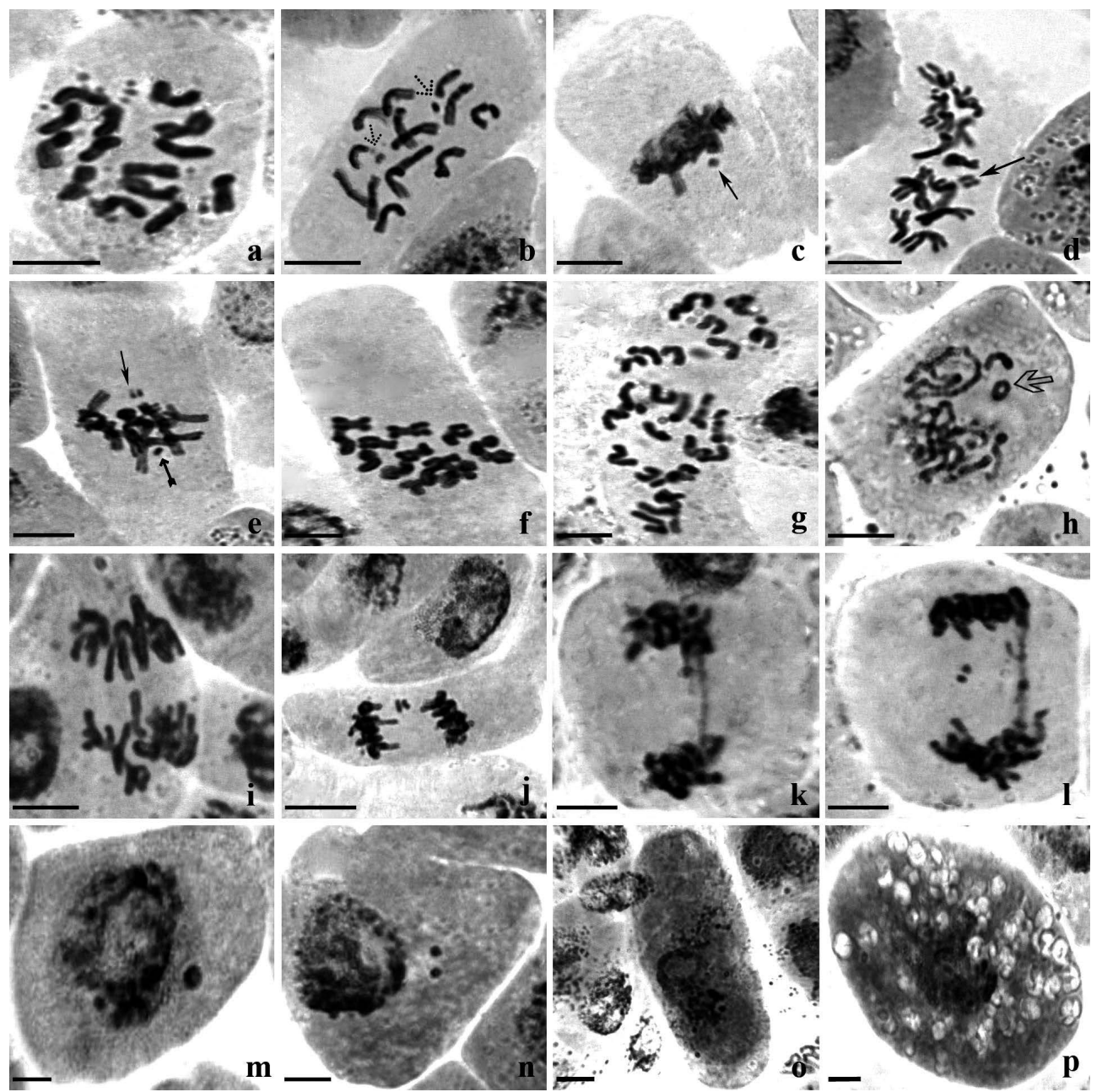

i.
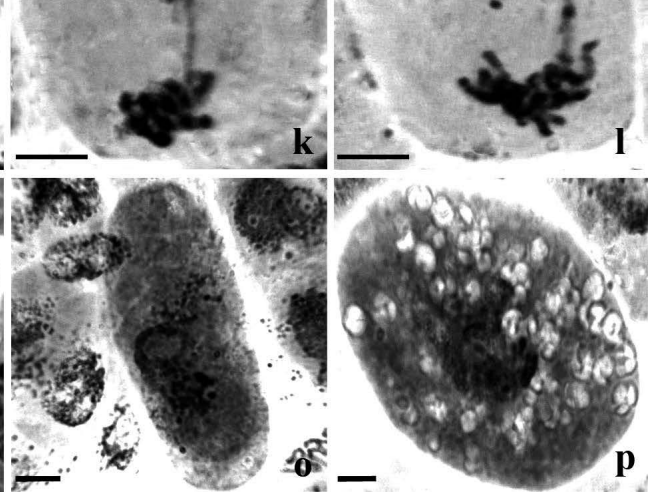

Fig. 1. NPs induced mitotic configurations at prophase (h), metaphase (a-g), anaphase (i-1) and resting stages (m-p). (a) $2 n=14$. (b) Gaps $(\rightarrow$ ). (c) Stickiness with paired fragments $(\rightarrow$ ). (d) Paired fragments $(\rightarrow$ ). (e) Paired $(\rightarrow$ ) and unpaired $(\rightarrow$ ) fragments. (f) Pseudo-chiasmata. (g) Polyploidy $2 n=28$. (h) Ring ( $\lesseqgtr$ ). (i) Multipolarity. (j) Paired fragments at anaphase. (k) Bridge. (1) Bridge with paired fragments. (m-n) Micronuclei. (o) Giant cell. (p) Vacuolated giant cell. Scale bar $=10 \mu \mathrm{m}$. 
ered blockage of cells into mitosis as the most important cellular event after mutagenic treatment.

Cells with $2 n=14$ (Fig. 1a) chromosomes are mostly observed in treatments. Stickiness of chromosomes and occasional laggard formation are studied in controls (Table 2). Types of aberration (Fig. 1b-p) observed in NP treatments are categorized in Table 2 . They are possibly the outcome of breakages and interchanges, spindle malfunctioning and cellular metabolic disorders. Cells with paired fragments are notably observed in both metaphase and anaphase. Ghasem et al. (2011) performed karyotype analysis of different germplasms of L. sativus and reported mostly one and rarely two pairs of chromosomes with satellites. In the present study, paired fragments (Fig. 1c-e, j, l) may have arisen due to breakage of a satellite pair of chromosomes or breaks in identical site of chromatids. Ionizing radiations are reported to induce localized breakages in chromosomes possessing sub-terminal constrictions in Nigella damascena (Moutschen 1968) and N. sativa (Datta and Biswas 1983).

Micronuclei (one to two) of variable (Fig. 1m, n) sizes (condensed and uncondensed) are found to occur in NP treatments, suggesting their effective potentiality to induce chromosomal breakages. Giant cells with and without vacuoles (Fig. 1o, p) are observed in resting cells. Vacuolated giant cells are mostly noted in higher doses of NPs. Extensive vacuolation has been attributed to the cellular attempts of compartmentalizing NPs to reduce the phytotoxicity associated to its exposure (Li et al. 2014, Thakur et al. 2014). Both NPs induce similar type of responses with respect to mitotic aberrations.

\section{Conclusion}

The types of aberration observed in NP treatments are rather similar to the genotoxic effects induced following $\mathrm{X}$-ray and gamma irradiations, suggesting the mutagenic potentiality of the studied nanoparticles. Genotype sensitivity of NP treatments is significant for potential effectiveness in inducing genetic variations.

\section{Acknowledgements}

The authors are thankful to Horticultural Research Station, Nadia, West Bengal for generous supply of the germplasm.

\section{References}

Atha, D. H., Wang, H., Petersen, E. J., Cleveland, D., Holbrook, R. D., Jaruga, P., Dizdaroglu, M., Xing, B. and Nelson, B. C. 2012. Copper oxide nanoparticle mediated DNA damage in terrestrial plant models. Environ. Sci. Technol. 46: 1819-1827.

Datta, A. K. and Biswas, A. K. 1983. X-ray sensitivity in Nigella sativa L. Cytologia 48: 293-303.

Evans, H. J. 1965. Effects of radiations on meristematic cells. Radiat. Bot. 5: 171-182.
Evans, H. J. and Sparrow, A. H. 1961. Nuclear factors affecting radiosensitivity. II. Dependence on nuclear and chromosome structure and organization. Brookhaven National Laboratory, Upton. pp. 101-127.

Ghasem, K., Danesh-Gilevaei, M. and Aghaalikhani, M. 2011. Karyotypic and nuclear DNA variations in Lathyrus sativus (Fabaceae). Caryologia 64: 42-54.

Gray, L. H. and Read, J. 1950. The effect of ionizing radiations on the broad bean root. VII. The inhibition of mitosis by alpha radiation. Br. J. Radiol. 23: 300-303.

Halder, S., Mandal, A., Das, D., Datta, A. K., Chattopadhyay, A. P., Gupta, S. and Kumbhakar, D. V. 2015a. Effective potentiality of synthesised $\mathrm{CdS}$ nanoparticles in inducing genetic variation on Macrotyloma uniflorum (Lam.) Verdc. Bionanoscience 5: 171-180.

Halder, S., Mandal, A., Das, D., Gupta, S., Chattopadhyay, A. P. and Datta, A. K. 2015b. Copper nanoparticle induced macromutation in Macrotyloma uniflorum (Lam.) Verdc. (Leguminosae): A pioneer report. Genet. Resour. Crop Evol. 62: 165-175.

Konzak, C. F., Nilan, R. A., Wagner, J. and Foster, R. J. 1965. Efficient chemical mutagenesis in the use of induced mutations in plant breeding. Radiat. Bot. 5: 49-70.

Kumbhakar, D. V., Datta, A. K., Mandal, A., Das, D., Gupta, S., Ghosh, B., Halder, S. and Dey, S. 2016. Effectivity of copper and cadmium sulphide nanoparticles in mitotic and meiotic cells of Nigella sativa L. (black cumin) - Can nanoparticles act as mutagenic agents? J. Exp. Nanosci. 11: 823-839.

Lea, D. E. 1946. Action of Radiations on Living Cells. Cambridge University Press, Cambridge.

Lee, H. L., Mohammed, I. A., Belmahi, M., Assouar, M. B., Rinnert, H. and Alnot, M. 2010. Thermal and optical properties of CdS nanoparticles in thermotropic liquid crystal monomers. Materials 3: 2069-2086.

Li, Y., Zhang, Y. and Yan, B. 2014. Nanotoxicity overview: Nanothreat to susceptible populations. Int. J. Mol. Sci. 15: 3671-3697.

Lin, B. S., Diao, S. Q., Li, C. H., Fang, L. J., Qiao, S. C. and Yu, M. 2004. Effect of TMS (nanostructured silicon dioxide) on growth of Changbai larch seedlings. J. For. Res. 15: 138-140.

Lu, C. M., Zhang, C. Y., Wen, J. Q., Wu, G. R. and Tao, M. X. 2002. Research of the effect of nanometer materials on germination and growth enhancement of Glycine $\max$ and its mechanism. Soybean Sci. 21: 168-171.

Ma, Y., Kuang, L., He, X., Bai, W., Ding, Y., Zhang, Z., Zhao, Y. and Chai, Z. 2010. Effect of rare earth oxide nanoparticles on root elongation of plants. Chemosphere 78: 273-279.

Manickathai, K., Kasi Viswanathan, S. K. and Alagar, M. 2008. Synthesis and characterization of $\mathrm{CdO}$ and $\mathrm{CdS}$ nanoparticles. Indian J. Pure App. Phys. 46: 561-564.

Masarovičová, E. and Král'ová, K. 2013. Metal nanoparticles and plants. Ecol. Chem. Eng. S. 20: 9-22.

Moutschen, J. H. 1968. Some implication of radio-induced structural changes of chromosome in N. damascena. Nucleus 11: 177-188.

Nair, R., Varghese, S. H., Nair, B. G., Maekawa, T., Yoshida, Y. and Sakthi Kumar, D. 2010. Nanoparticulate material delivery to plants. Plant Sci. 179: 154-163.

Read, J. 1959. Radiation Biology of Vicia faba in Relation to the General Problem. Blackwell Scientific Publications, Oxford. p. 270.

Sax, K. 1942. The mechanisms of X-ray effects on cells. J. Gen. Physiol. 25: 533-537.

Scrinis, G. and Lyons, K. 2007. The emerging nano-corporate paradigm: Nanotechnology and the transformation of nature, food and agri-food systems. Int. J. Sociol. Agric. Food 15: 22-44.

Shaymurat, T., Gu, J., Xu, C., Yang, Z., Zhao, Q., Liu, Y. and Liu, Y. 2012. Phytotoxic and genotoxic effects of $\mathrm{ZnO}$ nanoparticles on garlic (Allium sativum L.): A morphological study. Nanotoxicology 6: $241-248$. 
Thakur, M., Gupta, H., Singh, D., Mohanty, I. R., Maheswari, U., Vanage, G. and Joshi, D. S. 2014. Histopathological and ultra structural effects of nanoparticles on rat testis following 90 days (Chronic study) of repeated oral administration. J. Nanobiotech- nology 12: 42

Topnani, N., Kushwaha, S. and Athar, T. 2010. Wet synthesis of copper oxide nanopowder. Int. J. Green Nanotechnol. 1: M67-M73. 